\title{
P-Glycoprotein Expression on Patients with Acute Lymphoblastic Leukemia
}

\author{
R. Niruri ${ }^{1}$, I. Narayani ${ }^{2}$, K. Ariawati ${ }^{3}$, and S. Herawati ${ }^{4}$ \\ ${ }^{1}$ Department of Pharmacy, Faculty of Mathematic and Sciences, Udayana University \\ Bali-Indonesia \\ E-mail : rasmaya@yahoo.com \\ ${ }^{2}$ Department of Biology, Faculty of Mathematic and Sciences, Udayana University, \\ Bali-Indonesia \\ ${ }^{3}$ Divison of Hematology Oncology, Department of Pediatrician, Sanglah Hospital, \\ Bali-Indonesia \\ ${ }^{4}$ Department of Clinical Pathology, Faculty of Medicine, Udayana University, \\ Bali-Indonesia
}

\begin{abstract}
Objective: P-glycoprotein (P-gp) overexpression on neoplastic cells can deteriorate the therapeutic outcome on cancer patients. P-gp plays important role on drug efficacy and toxicity. This research aimed to measure P-gp expression on children with Acute Lymphoblastic Leukemia (ALL) on Sanglah Hospital, Denpasar. Method: Flowcytometry method was used to measure P-gp expression level on Bone Marrow samples from pediatric patients (0-12 years old) who were newly diagnosed with ALL in Sanglah Hospital. P-gp overexpression were based on the percentage of cell stained. Ten percent of P-gp expression were considered as the cut-off value of P-gp overexpression. Result: On this study, 11 samples were obtained with the range value of 56-97\% on P-gp expression. Conclusion: All 11 patients had P-gp overexpression.
\end{abstract}

Keywords : ALL children, BMA, P-gp

\section{INTRODUCTION}

P-glycoprotein (P-gp) overexpression can decrease intracellular drug concentration, such as vinblastine, vincristine, and daunomycin. P-gp may overexpressed on neoplastic cells. It can deteriorate the therapeutic response and prognosis on cancer therapy, such as on Acute Myeoblastic Leukemia (AML). P-gp plays important role in drug efficacy and toxicity [1], [2].

On leukemia, myeloma, lymphoma, and solid tumor (such as breast and ovarium cancer), the detection of drug resistances marker can help to choose drugs therapy. Low expression of P-gp can be a prediction marker on therapeutic result, such as in ovarium cancer [3], [4].

This study was aimed to evaluate P-gp expression on children with ALL in Sanglah Hospital, Bali.

\section{METHODS AND PROCEDURES}

This laboratory exploration study was approved by Ethical committee of Sanglah Hospital - Faculty of Medicine Udayana University.

\section{K. Samples}

Bone marrow aspirates (BMA) $(1 \mathrm{ml})$ were collected in ethylenediamine tetraacetic acid (EDTA) tubes from subjects (newly diagnosed children (0-12 years old) with ALL, who did not receive chemotherapy yet and signed inform consent) on the period of June 2015 - January 2016. The samples were sent to Clinical Pathology Laboratory, Dr Sutomo Hospital-Faculty of Medicine Airlangga University, Surabaya. P-gp Expression were measured in the period of 24 hours after the samples were drawn.

\section{P-gp expression}

$B D$ reagent anti $P$ - $g p$ PE dan $P E$ isotype control kappa IgG1A was used to study P-gp expression. The procedure was based on the manufacture instruction. Samples were run using FACS Calibur. P-gp positivity was determined based on the percentage (\%) of cells stained. Ten percent (10\%) of P-gp expression was considered as P-gp overexpression [5]-[7]. 


\section{RESULTS AND DISCUSSION}

Eleven samples were able to be studied. Only limited samples were collected because of limited patients, cell viability, and availability of reagents. Based on Mudita (2007), the total ALL cases on children at Sanglah Hospital were 51 cases on the period of 2000-2005 [8].

On this study, all the subjects had P-gp overexpression with the range of $56-97 \%$ (Table I and Figure 1).

TABLE I

P-GP EXPRESSION ON PATIENTS WITH ALL

\begin{tabular}{ccccc}
\hline \hline \multirow{2}{*}{ Subject } & $\begin{array}{c}\text { Number of } \\
\text { Cell Stained }\end{array}$ & $\begin{array}{c}\text { Cell } \\
\text { Total }\end{array}$ & $\begin{array}{c}\% \text { P-gp } \\
\text { positivity } \\
\text { (A/B)x 100\% }\end{array}$ & $\begin{array}{c}\text { P-gp } \\
\text { overexpression } \\
+/-\end{array}$ \\
\cline { 2 - 4 } & $A$ & $B$ & $C$ & + \\
\hline 1 & 5298 & 7440 & $71 \%$ & + \\
3 & 7683 & 9327 & $82 \%$ & + \\
4 & 5147 & 9147 & $56 \%$ & + \\
5 & 3303 & 4032 & $82 \%$ & + \\
6 & 3304 & 3899 & $56 \%$ & + \\
7 & 7210 & 7383 & $97 \%$ & + \\
8 & 8368 & 8589 & $97 \%$ & + \\
9 & 4233 & 6168 & $68 \%$ & + \\
10 & 3550 & 6228 & $57 \%$ & + \\
11 & 4372 & 5989 & $73 \%$ & + \\
\hline \hline
\end{tabular}

${ }^{\mathrm{a}} \mathrm{P}$-gp expression on patients with ALL; $(+)=\mathrm{P}$-gp overexpression; $(-)=$ normal P-gp expression.

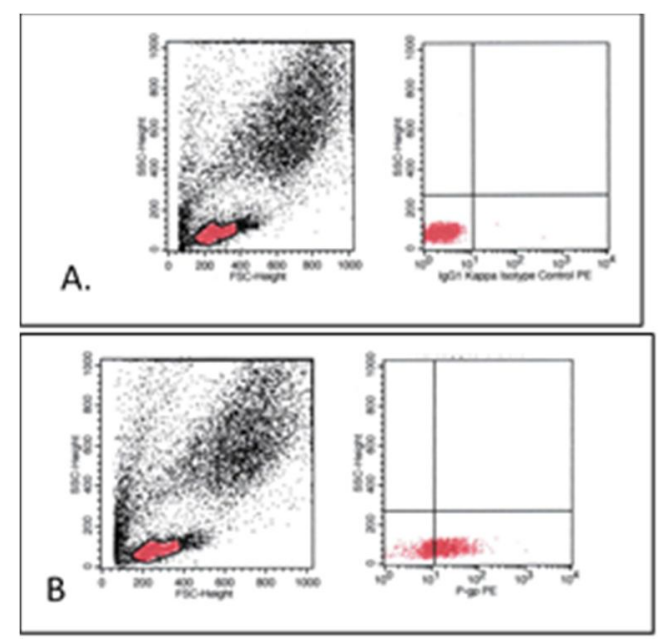

Fig. 1. Example of Flow Cytometry Results on Patients number 1 (A) Cell stained with Isotype Control,

(B) P-gp positive Cells (Upper Right and Lower Right Quadrant)

On all 11 patients (Table 1 and Figure 1) had P-gp overexpression. P-gp is the member of ATP-binding cassette $(\mathrm{ABC})$ transporter family. Hydrophobic medicines (such as vincristine, vinblastine, doxorubicin, and daunorubicin) entry across plasma membrane by diffusion. The activation of energy dependent transport systems can keep the medicines out of cells. It may reduce the drug accumulation on cancer cells [3], [9].

On this study, the P-gp expression on all 11 samples were on the range of 56-97\% (Table 1). Genetic variation on Multi Drug Resistance-1 (MDR-1) gene, which encoded $\mathrm{P}$-gp, was considered as one of the factors that alter P-gp function and expression [10]-[14]. Many studies in pharmacogenetics and pharmacogenomics showed that variation on Single Nucleotide Polymorphisms (SNP) of MDR-1 gene may affect the function and expression of Pgp in different ethnic-populations [2], [15]-[17]. There were 28 exon in MDR-1 gene. Based on the data from National Center for Biotechnology Information (NCBI), more than 50 SNPs from MDR-1 gene were found in human. High frequency of variant 3435, 2677, and 1236 MDR-1 Gene were found in Chinese, Malays, Iran, and India [3], [9], [18]-[21]. Haplotype may affect the secondary structure of mRNA and its activity. It will influence the efflux transporter activity and the drug therapeutic response [11], [22]. The difference on haplotype and phenotype can make alteration on $m R N A$ level, protein expression, protein folding, and a substrate specificity [3], [11], [23].

Variation on MDR-1 gene may influence on diseases progression and therapeutic outcome [3], [24]. In AML, addition of P-gp inhibitor on chemotherapy regimen can increase the probability of remission and survival rate [9], [25]. Mutation on MDR-1 gene may influence the P-gp inhibitor activity. The mutation on haplotype MDR-1 gene may alter the substrate binding site [3]. Therefore, further research need to be conducted to identify MDR-1 Gene variation and its association with the P-gp expression level and function in children with ALL in Bali.

\section{CONCLUSION}

P-gp overexpression was detected on all 11 patients in this study. Further research need to be conducted to identify polymorphisms on MDR - 1 Gen MDR-1 and its impact on P-gp expression level and function

\section{REFERENCES}

[1] L. M. Hodges, S. M. Markova, L. W. Chinn, J. M. Gow, D. L. Kroetz, T. E. Klein, and R. B. Altman. (2011, March). Very important pharmacogene summary: $A B C B 1$ (MDRl, Pglycoprotein). Pharmacogenet Genomics. [Online]. 21(3). pp. 152-161. Available: https://www.ncbi.nlm.nih.gov/pubmed/20216335

[2] L. Yan-Hong, W. Yong-Hua, L. Yan, Y. Ling. (2006, February). MDR1 Gene Polymorphisms and Clinical Relevance. Acta Genetica Sinica. [Online]. 33 (2). pp. 93-104. Available: http://www.sciencedirect.com

/science/article/pii/S0379417206600279?via\%3Dihub

[3] K. L. Fung and M.M. Gotte. (2009, May). A synonymous polymorphism in a common MDR1 (ABCB1) haplotype shapes protein function. Biochim Biophys Acta. [Online]. 1794(5). pp. 860871. Available: https://www.ncbi.nlm.nih.gov/pubmed/19285158

[4] H.J. Broxterman. 1996. How to Probe Clinical Tumour Samples for P-glycoprotein and Multidrug Resistance-associated Protein. European Journal of Cancer. [Online]. 33A(6). pp. 1024-1033. Available: https://www.ncbi.nlm.nih.gov/pubmed/8763344

[5] A. L. Dogan, A. Kars, H. Canpinar, D. Güç, M. Hayran, W. E. Criss, E. Kansu. (2004). Prediction of Clinical Response to Chemotherapy by In Vitro Chemosensitivity Assay In Acute Leukemia. Turkish Journal of Cancer. [Online]. 34(2). pp. 75-80. Available: http://www.turkjcancer.org/pdf/pdf_TJC_367.pdf

[6] V. NÜssler, R. Pelka-Flescher, H. Zwierzina, C. Nerl, B. Beckert, F. Gieseler, H. Diem, Ledderose G, E. Gullis, H. Sauer, W. Wilmanns. 
(1996, July). P-glycoprotein expression in patients with acute leukemia-clinical relevance. Leukemia. [Online]. 10(Suppl 3). pp. S23-S31. Available: https://www.ncbi.nlm.nih.gov/pubmed/8656697

[7] V. NÜssler, R. Pelka-Flescher, H. Zwierzina, C. Nerl, B. Beckert, E. Gullis, F. Gieseler, S. Bock, R. Bartl, P. E. Petrides, et al. (1994). Clinical Importance of P-glycoprotein-related resistance in Leukemia and Myelodysplastic Syndromes-First Experience with Their Reversal. Ann. Hematol. [Online]. 69 (Suppl 1). pp. S25-9. Available: http://link.springer.com/article/10.1007/BF01757351

[8] I B. Mudita. (2007). Pola Penyakit dan Karakteristik Pasien Hemato Onkologi Bagian Ilmu Kesehatan Anak Fakultas Kedokteran Universitas Udayana / Rumah Sakit Sanglah Periode 2000-2005. Sari Pediatri. [Online]. 9(1). pp. 13-16. Available: https://www.researchgate.net/publication/312404291_Pola_Penyakit _dan_Karakteristik_Pasien_Hemato_Onkologi_Bagian_Ilmu_Keseha tan_Anak_Fakultas_Kedokteran_Universitas_UdayanaRS_Sanglah_ Denpasar_Periode_2000-2005

[9] S. V. Ambudkar, C. Kimchi-Sarfaty, Z. E. Sauna and M. M. Gottesman. (2003). P-glycoprotein: from genomics to mechanism. Oncogene. [Online]. 22. pp. 7468-7485. Available: https://www.ncbi.nlm.nih.gov/pubmed/14576852

[10] J. M. Gow, L. M. Hodges, L. W. Chin, D. L. Kroetz. (2008). Substrate - Dependent Effect of Human ABCB1 Coding Polymorphisms. J Phamacol Exp Ther. [Online]. 325(2). pp. 435 442. Available: http://jpet.aspetjournals.org/content/jpet/325/2/435. full.pdf

[11] C. Kimchi-Sarfathy, J. M. Oh, I. W. Kim, Z. E. Sauna, A. M. Calcagno. S. V. Ambudkar, M. M. Gottesman. (2007). A Silent Polymorphism in the MDR-1 Gene Changes Substrate Specificity. Science. [Online]. 315. pp. 525-528. Available: https://www.ncbi.nlm.nih.gov/pubmed/17185560

[12] N. N. Salama, Z. Yang, T. Bui, R. J. Ho. (2006). MDR 1 Haplotypes Significantly Minimize Intracellular Uptake and Transcellular P-Gp Substrate Transport in Recombinant LLC-PK1 Cells. Journal of Pharmaceutical Sciences. [Online]. 95. pp. 2293 - 2308. Available: https://www.ncbi.nlm.nih.gov/pubmed/16883550

[13] D. L. Kroetz, C. Pauli-Magnus, L. M. Hodges, C. C. Huang, M. Kawamoto, S. J. John, D. Stryke, T. E. Ferrin, J. De Young, T. Taylor, E. J. Carlson, I. Herskowitz, K. M. Giacomini, A. G. Clark. (2003). Sequence Diversity And Haplotype Structure in Human ABCB1 (MDR1, Multi Drug Resistance Transporter) Gene. Pharmacogenetics. [Online]. 13. pp. 481-494. Available: https://www.ncbi.nlm.nih.gov/pubmed/16883550

[14] M. K. Leabman, C. C. Huang, J. D. Young, E J. Carlson, T. R. Taylor, D. L. M. Cruz, S. J John, D. Stryke, M. Kawamoto, T. J. Urban, D. L. Kroetz, T. E. Ferrin, A. G. Clark, N. Risch, I. Herskowitz, K. M. Giacomini. (2003). Natural Variation In Human Membrane Transpoter Genes Reveals Evolutionary and Functional Constrains. Proc Natl Acad Sci USA. [Online]. 100. pp. 5896 - 5901. Available: http://www.pnas.org/content/100/10/5896.full.pdf

[15] S. Hoffmeyer, O. Burk, O Richter, H. P. Arnold, J. Brockmoller, A. Johne, I. Cascorbi, T. Gerloff, I. Roots, M. Eichelbaum, U. Brinkmann. (2000). Functional polymorphisms of the human multidrug resistance gene: multiple sequence variations and correlation of one allele with P-glycoprotein expression and activity in vivo. Proc NatlAcad Sci USA. [Online]. 97. pp. 3473-3478. Available: https://www.ncbi.nlm.nih.gov/pubmed/10716719
[16] R. B. Kim, B. F. Leake, E. F. Choo, G. K. Dresser, S. V. Kubba, U. I. Schwarz, A. Taylor, H. G. Xie, J. McKinsey, S. Zhou, L. B. Lan, J. D. Schuetz, E. G. Schuetz, G. R. Wilkinson. (2001). Identification of functionally variant $M D R 1$ alleles among European Americans and African Americans. Clin Pharmacol Ther. [Online]. 70. pp. 189-199. Available: https://www.ncbi.nlm.nih.gov/pubmed/11503014

[17] M. M. Ameyaw, F. Regateiro, T. Li, X. Liu, M. Tariq, A. Mobarek, N. Thornton, G. O. Folayan, J. Githang'a, A. Indalo, D. Ofori-Adjei, D. A. Price-Evans, H. L. McLeod. (2001). MDR1 pharmacogenetics: frequency of the C3435T mutation in exon 26 is significantly influenced by ethnicity. Pharmacogenetics. [Online]. 11. pp. 217221. Available: https://www.ncbi.nlm.nih.gov/pubmed/11337937

[18] M. Saidijam, H. Mahjub, N. Shabab, R. Yadegarazari, (2015). Simultaneous Analyisis of Multidrug Resistance 1 (MDR-1) C3435T, G 2677 T/A, and C1236T Genotype in Hamadan City Population, West of Iran. Iranian Biomedical Journal. [Online]. 19(1). pp. 57-62. Available: https://www.ncbi.nlm.nih.gov/pmc/articles/PMC4322234/

[19] A. J. Brambilla-Tapia. (2013). MDR 1 (ABCB1) polymorphisms: functional effects and Clininal Implications. Revista de Investigacon Clinica. [Online]. 65(5). pp. 445 -454. Available: https://www.ncbi.nlm.nih. gov/pubmed/24687344

[20] K. Tang, S. M. Ngoi, P. C. Gwee, J. M. Chua, E. J. Lee, S. S. Chong and C. G. Lee. (2002). Distinct Haplotype Profiles And Strong Linkage Disequilibrium At The MDR1 Multidrug Transporter Gene Locus In Three Ethnic Asian Populations. Pharmacogenetics. [Online]. 12. pp. 437-450. Available:https://www.ncbi.nlm.nih.gov/ pubmed/12172212

[21] C. J. Chen, D. Clark, K. Ueda, I. Pastan, M. M. Gottesman and I. B. Roninson. (1990, January). Genomic Organization of Human Multidrug Resistance (MDR1) Gene and Origin of P-Glycoprotein. $J$ Biol Chem. [Online]. 265(1). pp. 506-514. Available: https://www.ncbi.nlm.nih.gov/pubmed/1967175

[22] D. Vivona, L. T. Lima, A. C. Rodrigues, C. T. Bueno, G. K. S. Alcantara, L. S. R. Barbos, V. T. D. M. Hungria, C. S. Chiattone, M. D. L. L. D. Chauffaille, E. M. Guerra-Shinohara. (2014). ABCB1 Haplotype are Associated with P-gp Activity and Affect a Major Molecular Response in Chronic Myeloid Leukemia Patients Treated with A standard Dose of Imatinib. Oncology Letters. [Online]. 7. pp. 1313-1319. Available: https://www.ncbi.nlm.nih.gov/pubmed/24660 038

[23] K. L. Fung and M. M. Gottesman. (1794). A synonymous polymorphism in a common MDR1 (ABCB1) haplotype shapes protein function. Biochim Biophys Acta. 1794. pp. 860-871.

[24] A. Ashariati, (2008, October). Polymorphism C3435T of The MDR1 Gene Predict Response to Preoperative Chemotherapy in Locally Advanced Breast Cancer with Her 2/ neu Expression. Acta med Indones, [Online]. 40(4). pp. 187-91. Available: https://www.ncbi.nlm.nih.gov/pubmed/19151448

[25] A. F. List, K. J. Kopecky, C. L. Willman, D. R. Head, D. L. Persons, M. L. Slovak, R. Dorr, C. Karanes, H. E. Hynes, J. H. Doroshow, M. Shurafa and F. R. Appelbaum. (2001). Benefit of cyclosporine modulation of drug resistance in patients with poor-risk acute myeloid leukemia: a Southwest Oncology Group study. Blood, [Online]. 98. pp. 3212-3220. Available: https://www.ncbi.nlm.nih.gov/pubmed ?cmd=Link \&dbFrom $=$ PubMed\&from_uid=8874180 